\title{
Calcium stimulation of gastrin and gastric acid secretion: effect of small doses of calcium carbonate
}

\author{
J BEHAR, ${ }^{1}$ M. HITCHINGS, AND R. D. SMYTH
}

From the Department of Medicine of the Veterans Administration Hospital and Yale University School of Medicine, West Haven, Connecticut, and the Rorer Institute of Research, Fort Washington, Pennsylvania, USA

SUMMARY Oral calcium carbonate $(0.5 \mathrm{~g}, \mathrm{pH} 9.4)$ increased serum gastrin and gastric acid output with slight but insignificant change in serum calcium. A similar rise in serum calcium during an intravenous infusion of calcium gluconate failed to increase serum gastrin and gastric acid output. Both intragastric calcium actions were abolished by acidification of the calcium carbonate solution (pH 1.0). The increase in serum gastrin and gastric acid output after intragastric calcium carbonate was not affected, however, by a simultaneous intraduodenal acid load. Equivalent neutralising doses of magnesium hydroxide ( $\mathrm{pH}$ 9.4) did not increase serum gastrin and gastric acid output above basal levels, whereas antral acidification with $20 \mathrm{ml} 0.1 \mathrm{~N} \mathrm{HCl}$ resulted in a slight decrease in serum gastrin. Intraduodenal calcium carbonate $(\mathrm{pH} 3.0)$ also increased serum gastrin and gastric acid output, whereas an equivalent volume of intraduodenal saline (pH 3.0) had no effect. These findings indicate that calcium increases serum gastrin by local stimulation of antral and duodenal mucosa. They also suggest that the action of calcium on gastric secretion is partly mediated by gastrin.

Calcium increases the serum levels of immunoreactive gastrin and stimulates gastric acid secretion (Barreras, 1973). Intravenous administration of calcium gluconate causes a progressive rise in serum calcium, stimulates gastric acid secretion (Murphy et al., 1966; Barreras and Donaldson, 1967; Smallwood, 1967), and increases the levels of serum gastrin (Reeder et al., 1970). Oral ingestion of calcium stimulates acid secretion in duodenal ulcer patients in both the fasting and post-cibal states (Barreras, 1970; Fordtran, 1968), with a concomitant increase in serum gastrin (Reeder et al., 1971).

However, the mechanisms whereby calcium increases the serum levels of immunoreactive gastrin and stimulates gastric acid secretion have not been conclusively defined. There is conflicting evidence as to whether ingestion of calcium carbonate selectively increases gastrin by virtue of calcium (Levant et al., 1973) or as the result of antral alkalinisation (McGuigan and Trudeau, 1970; Hansky et al., 1971). Furthermore, it has been proposed that calcium-

${ }^{1}$ Address for reprint requests: Dr Jose Behar, Rhode Island Hospital, 593 Eddy Street, Providence, R.I. 02902, USA

Received for publication 10 December 1976 stimulated gastric acid secretion is partly mediated by gastrin. The possibility, however, that the increase in serum gastrin and gastric secretion in response to calcium are parallel but independent phenomena has not been excluded (Levant et al., 1973; Rosato et al., 1973).

The present studies were designed to investigate the interaction of calcium, serum levels of immunoreactive gastrin, and gastric acid secretion with respect to: (1) the site of calcium stimulation; and (2) whether the calcium effect on gastric acid secretion is mediated by gastrin.

\section{Methods}

Twenty-five male patients with uncomplicated duodenal ulcer (DU) were studied. Their mean average was 54 years. DU was documented by upper gastrointestinal radiographs and/or duodenoscopy. Patients with duodenal ulcer participated at least in two and in as many as five paired studies. The means \pm SD of basal acid secretion (BAO) was $6.8 \pm 4.5$ and histamine-stimulated gastric acid secretion (PAO) was $40.2 \pm 10.0 \mathrm{mEq}$ per hour. Informed consent was obtained from all patients. 


\section{TECHNIQUES}

Paired, randomised gastric secretory studies were carried out after a 12 hour overnight fast. A radioopaque Levin Tube (F no. 14) was placed in the most dependent portion of the stomach under fluoroscopic control. After the stomach was completely emptied, basal and stimulated gastric secretions were collected by continuous pump and hand suction. Gastric juice hydrogen ion concentration was determined by the $\mathrm{pH}$ electrode (Moore and Scarlata, 1965). The neutralising equivalence of $\mathrm{CaCO}_{3}$ and $\mathrm{MgOH}$ was determined in vitro (US Pharmacopeia, 1970). Each test was performed on a different day.

Total serum and gastric juice calcium were determined by atomic absorption spectroscopy. Serum gastrin was determined by radioimmunoassay by a modification of previously described methods (McGuigan and Trudeau, 1970; Yalow and Berson, 1970; Stadil and Rehfeld, 1973). All serum samples were stored at $-25^{\circ} \mathrm{C}$ within one hour of collection and remained at this temperature until immediately before assay. Synthetic human gastrin (Imperial Chemical Industries, England) (SHG-I) and rabbit antiserum cospecific for SHG-I and II (Calbiochem Corp., California) were used. SHG-I was iodinated by a modification of the chloramine-T procedure (Hunter and Greenwood, 1962) with $\mathrm{Na}^{125} \mathrm{I}$ (Amersham Searle Corp., Chicago, Ill.) (less than $\left.1 \%{ }^{126} \mathrm{I}\right)$. All assays were performed in triplicate on two separate occasions. Gastrin values from individual assays were determined as a mean gastric value $(n=6)$, and its concentration expressed in picomole of immunoreactive gastrin/l serum (Stadil and Rehfeld, 1973). The coefficient of variation was less than $6 \%$ over a range of 12 to $210 \mathrm{pmol}$ gastrin/l serum.

In vitro binding of calcium to gastric juice proteins was studied using pooled gastric juice and Amicon Centriflo ultrafiltration cones (Amicon Corp., Lexington, Mass.) for separation of free and protein bound calcium. Gastric juice was obtained during histamine stimulation from six DU patients and collected at $4^{\circ} \mathrm{C} ; 0.555 \mathrm{~g}(5 \mathrm{mmol})$ calcium chloride was added to $20 \mathrm{ml}$ aliquots of gastric juice and the final pH was adjusted with $\mathrm{HCl}$ or $\mathrm{NaOH}$ to $\mathrm{pH}$ $1 \cdot 0,2 \cdot 0,3 \cdot 0,4 \cdot 0$, and $7 \cdot 0$. Each aliquot was allowed to equilibrate in a water bath at $37^{\circ}$ with continuous and gentle shaking for 30 minutes. Then $5 \mathrm{ml}$ of the test sample was pipetted into the ultrafiltration cone. The assembly was centrifuged at $800 \mathrm{rpm}$ for 10 minutes to collect a volume of ultrafiltrate (U) equivalent to approximately $10 \%$ of the original (O) volume. Calcium concentration was determined in the $U$ and $O$ samples. The percent calcium bound to gastric juice proteins is the difference between the two concentrations (C) and calculated as follows:

$$
\% \mathrm{CA} \text { bound }=\frac{\mathrm{CO}-\mathrm{CU}}{\mathrm{CO}} \times 100
$$

\section{EXPERIMENTAL DESIGN}

\section{Studies with calcium carbonate or magnesium hydroxide}

Experiments were performed with single doses of calcium carbonate $(0.5 \mathrm{~g})$ suspended in water $(\mathrm{pH}$ 9.4 ) or adjusted to $\mathrm{pH} 1.0$ or 3.0 with $\mathrm{HCl}$. Magnesium hydroxide gel was used at an equivalent neutralising dose of $0.4 \mathrm{~g}$ magnesium hydroxide in water ( $\mathrm{pH} \mathrm{9.4).}$ Basal gastric secretion was collected for 30 minutes immediately before the antacid administration. Then the antacid, in a final volume of $20 \mathrm{ml}$, was administered through the nasogastric tube. In certain studies $\mathrm{CaCO}_{3}(0.5 \mathrm{~g})$, saline or $\mathrm{HCl}$ solutions were instilled in the third portion of the duodenum through a radio-opaque tube $F$ no. 12 positioned under fluoroscopic control. The gastric tube was clamped for 25 minutes. The stomach was emptied for five minutes and gastric collections were obtained in subsequent 30-minute intervals $(30-60,60-90$, and 90-120 minutes). Blood samples were drawn 30 and 15 minutes before, and $30,60,90$, and 120 minutes after the antacid administration for analysis of serum calcium and gastrin.

\section{Studies with intravenous calcium gluconate}

Intravenous infusions of calcium gluconate were administered as previously described (Barreras and Donaldson, 1967). Patients received $2 \mathrm{mg}$ elemental calcium per $\mathrm{kg}$ of body weight per hour. Gastric secretion was collected in 30 minute periods during the saline (one hour) and calcium (two hours) infusions. Blood samples were obtained every 30 minutes for serum calcium and gastric determination.

\section{Statistical analysis}

The Willcoxon-sign test was applied to all experiments with six or more observations and the binomial distribution was applied to experiments with less than six observations.

\section{Results}

STUDIES WITH CALCIUM CARBONATE

Small doses of intragastric calcium carbonate in water $(\mathrm{pH} \mathrm{9.4)}$ increased serum gastrin $(\mathrm{P}<0.05)$ and gastric acid secretion $(P<0.001)$ above basal levels, without a significant increase in serum calcium concentration $(P>0.05)$ in six patients with DU (Fig. 1). The same dose of calcium carbonate adjusted to $\mathrm{pH} 1 \cdot 0$, however, did not cause an 

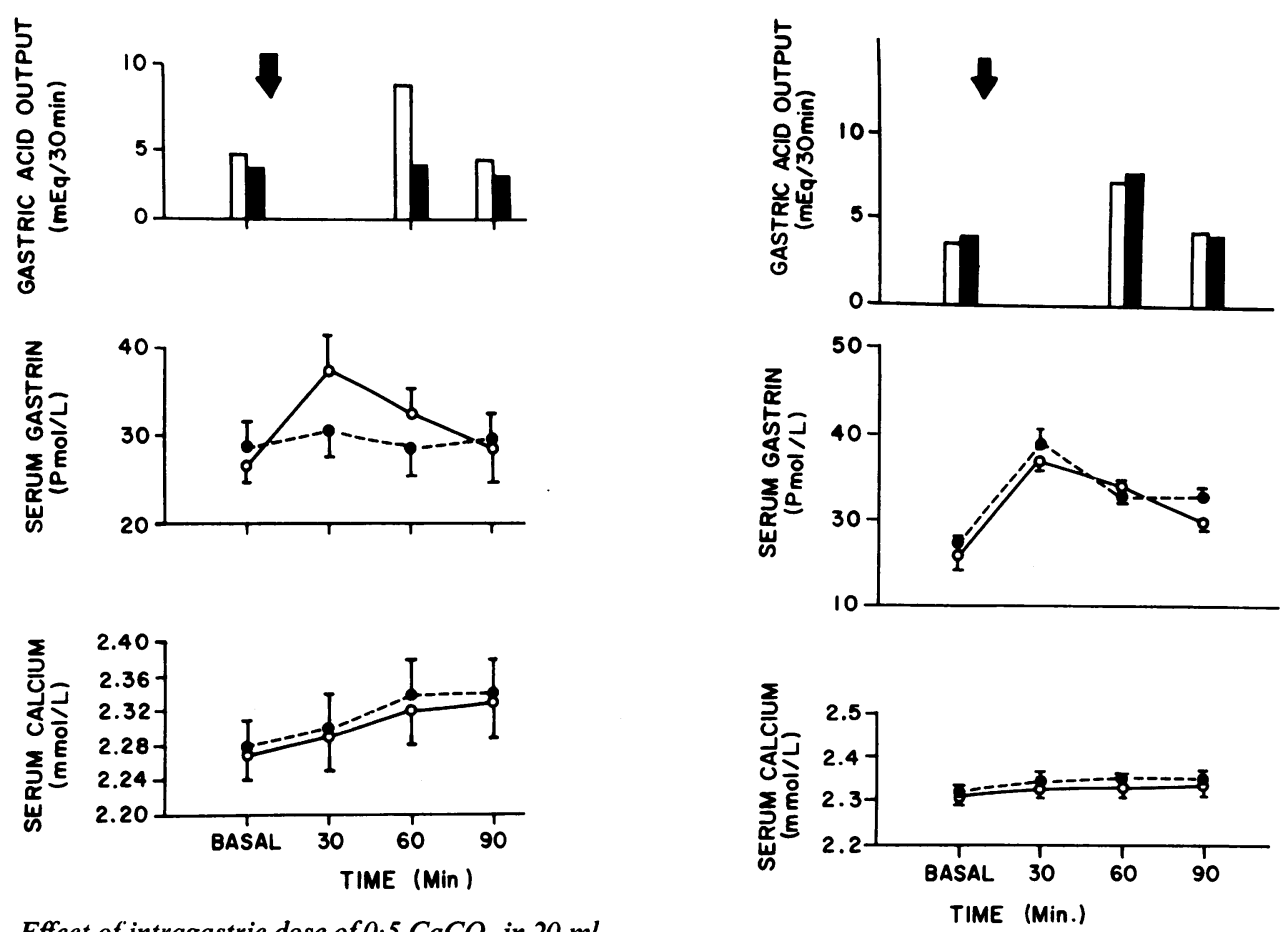

Fig. 1 Effect of intragastric dose of $0.5 \mathrm{CaCO}_{3}$ in $20 \mathrm{ml}$ water ( $p H$ 9.4) or in $20 \mathrm{ml} \mathrm{HCl}(\mathrm{pH} \mathrm{1.0)} \mathrm{on} \mathrm{serum} \mathrm{calcium,}$ serum gastrin, and gastric acid output in six $D U$ patients. Arrow indicates the timing of administration of test solution. Values of gastric acid output are means and of serum gastrin and calcium are means $\pm S E$. White symbols: $0.5 \mathrm{~g} \mathrm{CaCO}_{3}(\mathrm{pH} 9.4)$. Black symbols: $0.5 \mathrm{~g}$ $\mathrm{CaCo}_{3}(\mathrm{pH} \mathrm{1.0)}$

increase in serum gastrin and gastric acid output (P > 0.05). The effect of the final pH of the calcium solutions on antral $\mathrm{pH}$ was determined in separate studies in four of these patients. The antral $\mathrm{pH}$ was measured in $10 \mathrm{ml}$ aliquots of gastric juice collected before and at five minute intervals for 30 minutes. Basal pH of 1.3 increased after the administration of calcium carbonate ( $\mathrm{pH} \mathrm{9.4)}$ ) and remained above 5.5 throughout the 30 minute period. A decrease in antral $\mathrm{pH}$ was observed after calcium carbonate (pH 1.0) remaining below 1.3 for the 30 minute period.

To investigate the effect of acid on the calcium action, $0.5 \mathrm{~g} \mathrm{CaCO}_{3}$ (pH 9.4) was instilled in the antrum through a gastric tube and $20 \mathrm{ml} \mathrm{HCl}$ (pH 1.0) was instilled in the third portion of the duodenum through a duodenal tube, simultaneously. Under these experimental conditions, calcium caused an increase in serum gastrin $(P<0.05)$ and gastric acid output $(P<0.05)$ above basal levels in six patients with DU (Fig. 2). The increase in serum gastrin and gastric acid output after the simultaneous

Fig. 2 Serum calcium, serum gastrin, and gastric acid output in response to either simultaneous intragastric dose of $0.5 \mathrm{~g} \mathrm{CaCO}_{3}(\mathrm{pH} \mathrm{9.4)} \mathrm{and} 20 \mathrm{ml}$ intraduodenal $\mathrm{HCl}$ $(\mathrm{pH} \mathrm{1.0)}$ or to intragastric dose of $0.5 \mathrm{~g} \mathrm{CaCO}(\mathrm{pH} 9.4)$ alone in six DU patients. Arrow indicates the timing of administration of test solutions. Values of gastric acid output are means and of serum gastrin and calcium are means \pm SE. Antrum: $\bigcirc \square 0.5 \mathrm{~g} \mathrm{CaCO}_{3}(\mathrm{pH} \mathrm{9.4)} \mathrm{in}$ antrum; $0.5 \mathrm{~g} \mathrm{CaCO}_{3}(\mathrm{pH} 9.4)$ in the antrum and $20 \mathrm{ml} \mathrm{HCl}(p \mathrm{H} \mathrm{1} \cdot 0)$ in the duodenum

administration of intragastric calcium carbonate and intraduodenal $\mathrm{HCl}$ was not different from that observed after intragastric calcium carbonate alone ( $P>$ 0.05). Equivalent neutralising doses of magnesium hydroxide $(0.4 \mathrm{~g}$ in water, ph 9.4$)$ did not increase serum gastrin above basal levels (Fig. 3, P > 0.05) in six patients with DU. Administration of $20 \mathrm{ml}$ $0.1 \mathrm{~N} \mathrm{HCl}(\mathrm{pH} \mathrm{1.0)}$ in the antrum caused a slight decrease in serum gastrin below basal levels at 60 minutes $(P<0.05)$.

Studies were conducted in seven patients to determine the site of the action by performing the following experiments: (1) $\mathrm{CaCO}_{3}$ (pH 9.4) instilled in the antrum through the gastric tube or adjusted to $\mathrm{pH} 3.0$ instilled in the third portion of the duodenum through a duodenal tube. The concentration and output of calcium was measured in the gastric contents before and every 30 minutes after the administration of calcium carbonate in the duodenum. 

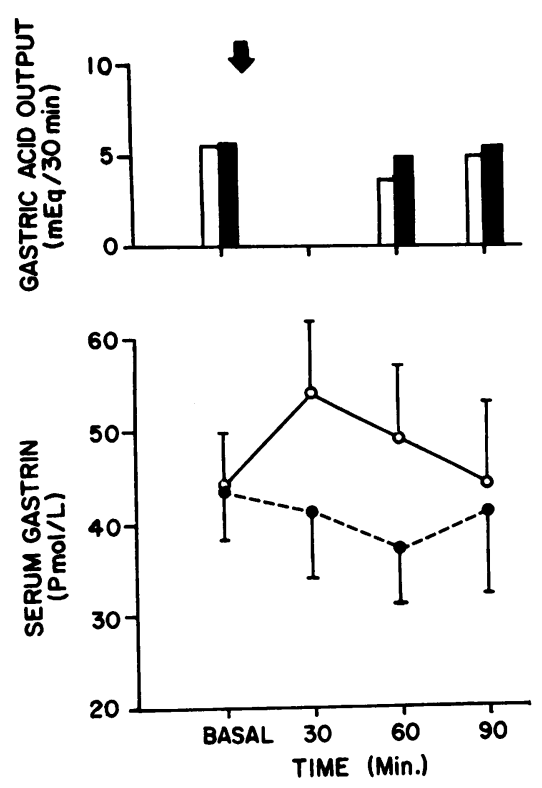

Fig. 3 Effect of intragastric dose of magnesium hydroxide $(0.4 \mathrm{~g})$ in $20 \mathrm{ml}$ water $(\mathrm{pH} \mathrm{9.4)}$ or of $20 \mathrm{ml} \mathrm{HCl}(\mathrm{pH} \mathrm{1.0)}$ on serum gastrin and gastric acid output in six DU patients. Arrow indicates the timing of administration of test solutions. Values of gastric acid output are means and of serum gastrin are means $\pm S E . \bigcirc \square \mathrm{MgOH} . \bigcirc \mathrm{HCl}$.

Any increase in total calcium in the gastric contents above basal levels was considered calcium reflux in the antrum. Two patients with calcium reflux in the antrum were excluded; and (2) $\mathrm{CaCO}_{3}$ or a similar volume of isotonic saline ( $\mathrm{pH} \mathrm{3.0)}$ was instilled in the third portion of the duodenum through a duodenal tube in the remaining five patients. Serum gastrin and gastric acid output increased above basal levels in response to calcium administration at pH 9.4 in the antrum $(\mathrm{P}<0.05)$ or $\mathrm{pH} 3.0$ in the duodenum $(P<0.05)$. Both secretory responses were equivalent ( $P>0.05$, Fig. 4). Serum gastrin and gastric acid output, however, did not increase in response to intraduodenal saline at $\mathrm{pH} 3.0$ (Fig. 5, $P>0.05)$.

\section{STUDIES WITH INTRAVENOUS CALCIUM GLUCONATE (Fig. 6)}

During the constant intravenous infusion of calcium gluconate, serum calcium steadily rose; however, the immunoreactive levels of serum gastrin and gastric acid output began to rise 60 minutes after the onset of the calcium infusion. An increase in serum calcium from $2.31 \pm 0.01$ to $2.38 \pm 0.2 \mathrm{mmol} / 1$ $(d=0.07 \mathrm{mmol} / \mathrm{l}) \mathrm{had}$ no effect on serum gastrin or gastric acid output.

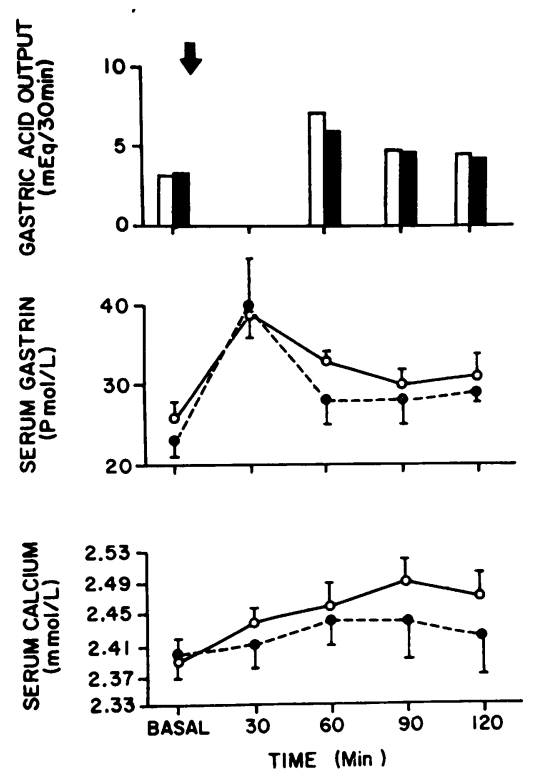

Fig. 4 Effect of intragastric dose $(0.5 \mathrm{~g})$ of calcium carbonate $(\mathrm{pH} 9.4)$ or of intraduodenal dose $(0.5 \mathrm{~g})$ of calcium carbonate ( $\mathrm{pH} 3.0)$ on serum calcium, serum gastrin, and gastric acid output in five DU patients. Arrow indicates the timing of administration of test solutions. Values of gastric acid output are means and of serum gastrin and calcium are means $\pm S E . \bigcirc \square$ Gastric. $\checkmark$ Duodenal

In vitro CALCIUM BINDING STUDIES

These experiments were designed to determine the influence of $\mathrm{pH}$ of gastric juice on calcium binding to protein. Deacidification of gastric juice caused a gradual increase in calcium binding in six in vitro studies. When compared with the calcium binding observed at $\mathrm{pH}$ of 1.0 and $2 \cdot 0$, alkalinisation of the aliquots of gastric juice increased the mean $\pm \mathrm{SE}$ binding of calcium by $4.2 \pm 0.4 \%$ at $\mathrm{pH} 3.0$ by $5.9 \pm 0.6 \%$ at $\mathrm{pH} 4.0$, and by $10.4 \pm 0.5 \%$ at $\mathrm{pH}$ $7.0(\mathrm{P}<0.05)$.

\section{Discussion}

Small doses of intragastric calcium carbonate $(0.5 \mathrm{~g})$ increased gastric acid secretion and serum levels of immunoreactive gastrin. These small doses of calcium carbonate caused a slight but statistically insignificant increase in serum calcium. Similar increases in serum calcium during intravenous infusion of calcium gluconate, however, failed to stimulate gastrin secretion and gastric acid output.

The specificity of the calcium effect was evidenced by the observation that equivalent neutralising doses 


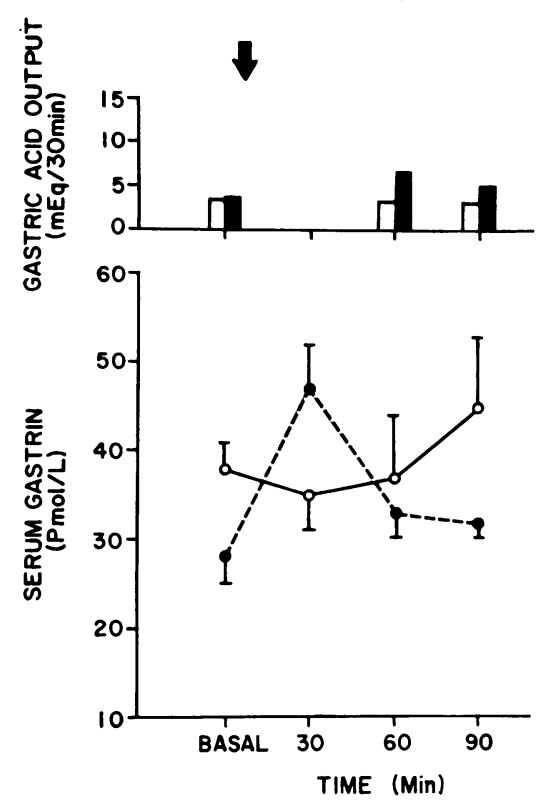

Fig. 5 Serum gastrin and gastric acid output in response to intraduodenal dose of $0.5 \mathrm{~g}$ calcium carbonate ( $p H$ 3.0) or $20 \mathrm{ml}$ saline ( $\mathrm{pH} \mathrm{3.0)}$ in five patients with DU. Arrow ndicates the timing of administration of test solutions. Values of gastric acid output are means and of serum gastrin are means $\pm S E . \bigcirc \square$ Saline. $\bigcirc 0.5 \mathrm{~g} \mathrm{CaCO}_{3}$
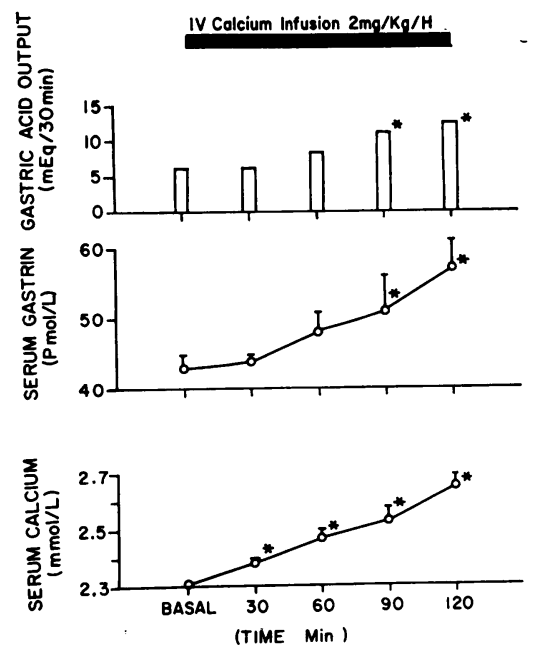

Fig. 6 Effect of intravenous saline (basal) and calcium gluconate $(2 \mathrm{mg} / \mathrm{kg}$ body $\mathrm{wt} / \mathrm{h})$ on serum calcium, immunoreactive levels of serum gastrin, and gastric acid output. Values of gastric acid output are means and of serum gastrin and calcium are means $\pm S E$ of six experiments. ${ }^{*}$ Means significantly greater than basal values of magnesium hydroxide did not increase gastrin or stimulate acid secretion. These calcium effects, however, were completely blocked by acidification of the calcium carbonate solution to $\mathrm{pH} \mathbf{1} \mathbf{0}$. Acidification of the calcium solution appears to inhibit the effect of calcium on the antral mucosa and perhaps on the fundic mucosa as well (Debas and Grossman, 1975), as these observations cannot be entirely explained by simultaneous inhibition of spontaneous gastrin secretion, by secretin stimulation, or by the gastric inhibitory response to intraduodenal acid. Evidence has been presented previously that exogenous secretin decreased basal serum levels of immunoreactive gastrin (Hansky et al., 1971) and that duodenal acidification inhibited the pentagastrin stimulated gastric acid secretion (Ward and Bloom, 1974) in duodenal ulcer patients. It is conceivable that the small intragastric and intraduodenal acid loads used in this study were not sufficient to stimulate the hormonal and neural mechanisms required to influence the effect of calcium carbonate on serum gastrin and gastric acid output. These findings are consistent with the hypothesis that small doses of calcium carbonate increase serum gastrin by local stimulation of the antral and duodenal mucosa which is favoured in an alkaline environment (Feurle, 1965). Thus, the action of calcium appears to be similar to the action of all other mucosal stimuli of antral gastrin which are inhibited by antral acidification (Redford and Schofield, 1965; Grossman, 1967).

The parallel increase in serum gastrin and gastric acid output in response to small doses of calcium carbonate, coupled with simultaneous inhibition by acidification of the calcium solution, suggest that calcium-stimulated gastric acid secretion could be partly mediated by gastrin. This assumption is further supported by the finding that calcium stimulates gastric acid secretion without coming in direct contact with parietal cells. In contrast with intraduodenal saline, small doses of calcium carbonate in the duodenum increased serum gastrin and gastric acid secretion without changing serum calcium significantly. Gastrin has been detected in the human duodenum by bioassay and immunoassay methods (Emås et al., 1971) and duodenal gastrin has been stimulated by amino-acids (Hayes et al., 1974). These findings, however, do not preclude the possibility that small doses of calcium carbonate stimulated parietal cell secretion by direct action which could be inhibited by acidification (Debas and Grossman, 1975; Holtermuller et al., 1974), or by additional humoral (Holtermuller et al., 1976) or neural mechanisms triggered from the stomach or duodenum (Harper et al., 1959; Sircus, 1953).

The physicochemical interactions of calcium 
carbonate and the components of gastric secretion were not adversely affected by acidification. Calcium must be solubilised to exert an effect and partial ionisation of calcium carbonate by adjustment to pH 3 is required to increase the serum levels of immunoreactive gastrin in patients with pernicious anaemia (Behar and Smyth, unpublished observations). Calcium binding to gastric proteins in vitro was also reduced by acidification, in accord with previous observations (Carr, 1955) of maximum binding of calcium to crystalline pepsinogen at $\mathrm{pH} 7 \cdot 4$.

In agreement with the concept advanced by Grossman that antral deacidification enhances the release of gastrin only in the presence of positive stimuli (Grossman, 1967), the antral action of small doses of calcium appears to require a relatively alkaline environment (Feurle, 1975). However, antral alkalinisation per se does not explain the calcium effect. Equivalent neutralising solutions of small doses of non-calcium antacids failed to increase serum gastrin and gastric acid output above basal levels (Barreras, 1970). Furthermore, partially solubilised (ionised) calcium carbonate is able to increase the levels of serum gastrin in patients with pernicious anaemia and histamine-achlorhydria.

In summary, these studies indicate that small doses of calcium carbonate increase the serum levels of immunoreactive gastrin by local stimulation of the antral and duodenal mucosa. They also suggest that calcium stimulation of gastric acid secretion is partly mediated by increasing the serum levels of immunoreactive gastrin. Additional direct calcium action on parietal cells or through neural and other humoral mechanisms could not be excluded.

We wish to thank Dr Robert Donaldson for his critical evaluation of this manuscript and $\mathrm{Mr}$ Emanuel Lerner for his statistical assistance. To Judy Johnson, Jon Kastendieck, and Martha Weed for invaluable technical assistance, and to Mary Murray for preparing the manuscript.

\section{References}

Barreras, R. F., and Donaldson, R. M. (1967). Effects of induced hypercalcemia on human gastric secretion. Gastroenterology, 52, 670-675.

Barreras, R. F. (1970). Acid secretion after calcium carbonate in patients with duodenal ulcer. New England Journal of Medicine, 282, 1402-1405.

Barreras, R. F. (1973). Calcium and gastric secretion. Gastroenterology, 64, 1168-1184.

Carr, C. W.(1955). Determination of ionic acitivity in protein solutions with collodion membrane electrodes. Electrochemistry in Biology and Medicine, p. 266. Edited by T. Shedlovsky. Wiley: New York.

Debas, H. T., and Grossman, M. I. (1975). Chemicals bathing the oxyntic gland area stimulate acid secretion in dog. Gastroenterology, 69, 654-659.
Emås, S., Borg, I., and Fyrö, B. (1971). Antral and duodenal gastrin activity in non-ulcer and ulcer patients. Scandinavian Journal of Gastroenterology, 6, 39-43.

Feurle, G. E. (1975). Effect of rising intragastric pH induced by several antacids on serum gastrin-concentrations in duodenal ulcer patients and in a control group. Gastroenterology, 68, 1-7.

Fordtran, J. S. (1968). Acid rebound. New England Journal of Medicine, 279, 900-905.

Grossman, M. I. (1967). Neural and hormonal stimulation of gastric secretion of acid. Handbook of Physiology, section 6, vol. 2, pp. 835-863. Edited by C. F. Code. American Physiological Society: Washington, D.C.

Hansky, J., Korman, M. G., Cowley, D. J., and Baron, J. H. (1971). Serum gastrin in duodenal ulcer. Gut, 12, 959-962.

Hansky, J., Soveny, C., and Korman, M. G. (1971). Effect of secretin on serum gastrin as measured by immunoassay. Gastroenterology, 61, 62-68.

Harper, A. A., Kidd, C., and Scratcherd, T. (1959). Vagovagal reflex effects on gastric and pancreatic secretion and gastrointestinal motility. Journal of Physiology, 148, 417-436

Hayes, J. R., Ardill, J., Kennedy, T. L., and Buchanan, K. D. (1974). A duodenal role in gastrin release. Gut, 15, 626-629.

Holtermuller, K. H., Goldsmith, R. S., Sizemore, G. W., and Go, V. L. W. (1974). Dissociation of gastric acid and serum gastrin responses to intraluminal calcium in man: influence of calcitonin and parathyroid hormone. Gastroenterology, 67, 1101-1106.

Holtermuller, K. H., Malagelada, J. R., McCall, J. T., and Go, V. L. W. (1976). Pancreatic, gallbladder, and gastric responses to intraduodenal calcium perfusion in man. Gastroenterology, 70, 693-696.

Hunter, W. M., and Greenwood, F. C. (1962). Preparation of iodine-131 labelled human growth hormone of high specific activity. Nature, 194, 495-496.

Levant, J. A., Walsh, J. H., and Isenberg, J. I. (1973). Stimulation of gastric secretion and gastrin release by single oral doses of calcium carbonate in man. New England Journal of Medicine, 289, 555-558.

McGuigan, J. E., and Trudeau, W. L. (1970). Studies with antibodies to gastrin. Radioimmunoassay in human serum and physiological studies. Gastroenterology, 58, 139-150.

Moore, E. W., and Scarlata, R. W. (1965). Determination of gastric acidity by the glass electrode. Gastroenterology, 49, 178-188.

Murphy, D. L., Goldstein, H., Boyle, J. D., Ward, S. (1966). Hypercalcemia and gastric secretion in man. Journal of Applied Physiology, 21, 1607-1610.

Nilsson, G., Yalow, R. S., and Berson, S. A. (1973). Distribution of gastrin in the gastrointestinal tract of human, dog, cat and hog. In Frontiers in Gastrointestinal Hormone Research, pp. 95-102. Edited by S. Andersson. Almqvist and Wiksell: Stockholm.

Redford, M., and Schofield, B. (1965). The effect of local anaesthesia of the pyloric antral mucosa on acid inhibition of gastrin-mediated acid secretion. Journal of Physiology, 180, 304-320.

Reeder, D. D., Jackson, B. M., Ban, J., Clendinnen, B. G., Davidson, W. D., and Thompson, J. C. (1970). Influence of hypercalcemia on gastric secretion and serum gastrin concentrations in man. Annals of Surgery, 172, 540-546.

Reeder, D. D., Conlee, J. L., and Thompson, J. C. (1971). Calcium carbonate antacid and serum gastrin concentration in duodenal ulcer. Surgical Forum, 22, 308-310.

Rosato, E. F., Mullen, J. L., Lanciault, G., Rosato, F. E., and Brooks, F. P. (1973). The dissociation of gastric acid output and plasma gastrin concentration after calcium infusions in conscious monkeys. Surgery, 73, 207-211.

Sircus, W. (1953). The intestinal phase of gastric secretion. Quarterly Journal of Experimental Physiology, 38, 91-100. 
Smallwood, R. A. (1967). Effect of intravenous calcium administration on gastric secretion of acid and pepsin in man. Gut, 8, 592-598.

Stadil, F., and Rehfeld, J. (1973). Determination of gastrin in serum. An evaluation of the reliability of a radioimmunoassay. Scandinavian Journal of Gastroenterology, 8, 101-112.
Ward, A. S., and Bloom, S. R. (1974). The role of secretin in the inhibition of gastric secretion by intraduodenal acid. Gut, 15, 889-897.

Yalow, R. S., and Berson, S. A. (1970). Radioimmunoassay of gastrin. Gastroenterology, 58, 1-14. 